\title{
Regulating the postharvest life of Campomanesia lineatifolia R. \& P. fruits through the interaction of ethylene, 1-methylcyclopropene and low temperatures
}

\section{Regulación de la vida poscosecha de frutos de Campomanesia lineatifolia R. \& P. mediante la interacción del etileno, 1-metilciclopropeno y bajas temperaturas}
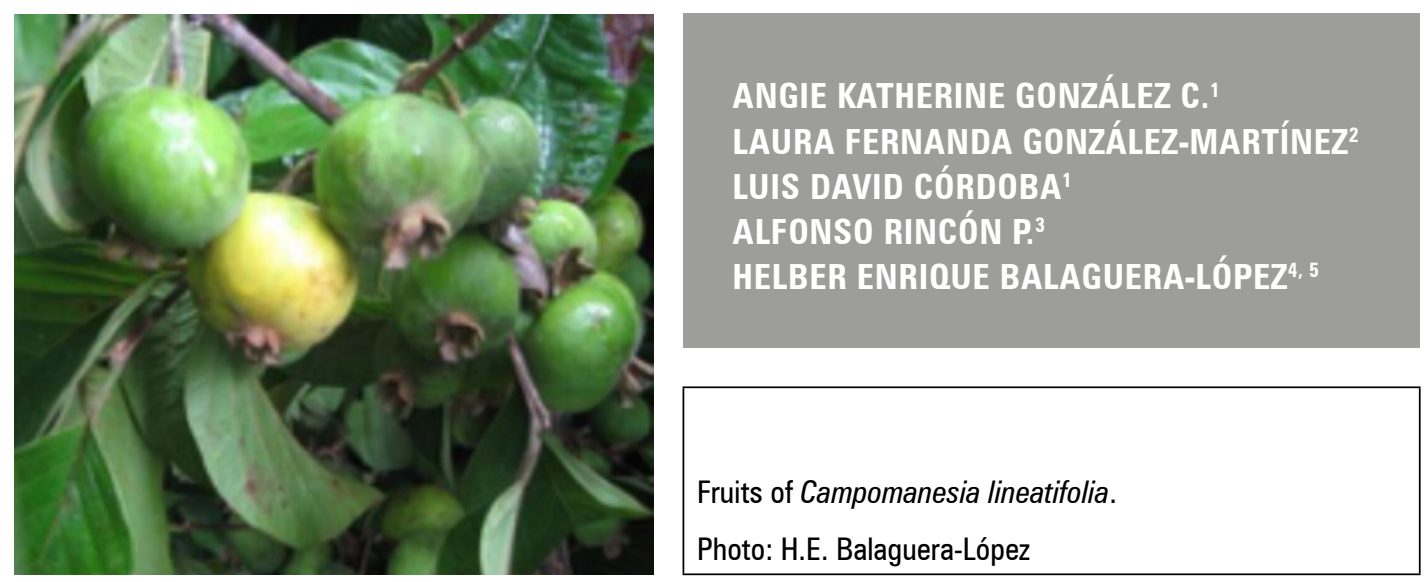

\begin{abstract}
The champa (Campomanesia lineatifolia) is a very perishability berry with a pleasant taste. The objective of this research was to study the regulation and prolongation of the postharvest conservation of champa fruits using 1-methylcyclopropene (1-MCP) and refrigeration. Two experiments were carried out: In experiment 1, four treatments were evaluated to understand the regulation of maturation. The treatments were: control, $1-\mathrm{MCP}$, ethylene and 1-MCP + ethylene. The fruits were stored at room temperature. In experiment 2, the combination of the application of 1-MCP and two storage temperatures (room temperature $\left[16 \pm 2^{\circ} \mathrm{C}\right]$ as well as $2 \pm 0.4^{\circ} \mathrm{C}$ ) were used. In the two experiments, four repetitions were used, each one with approximately 500 $\mathrm{g}$ of fruits harvested at stage 2 of maturity (25\% yellow and $75 \%$ green). The results of experiment 1 indicated that the fruits with 1-MCP presented the longest postharvest duration (17 days), firmness, and titratable acidity. They also had the lowest respiratory rate and weight loss during the 10 days. However, the fruits treated with ethylene had the opposite behavior, indicating that the changes evaluated during ripening were

1 Universidad Pedagógica y Tecnológica de Colombia, Programa de Ingeniería Agronómica, Tunja (Colombia). ORCID González, A.K.: 0000-0002-2105-7933, Córdoba, L.D.: 0000-0001-7936-3653

2 Universidad Pedagógica y Tecnológica de Colombia, Programa de Biología, Tunja (Colombia). ORCID González-Martínez, L.F.: 0000-0003-2052-6256

3 Universidad Pedagógica y Tecnológica de Colombia, Facultad de Estudios a Distancia FESAD, Tunja (Colombia). ORCID Rincón, A.: 0000-0003-4710-6665

4 Universidad Nacional de Colombia, Facultad de Ciencias Agrarias, Departamento de Agronomía, Bogota (Colombia). ORCID Balaguera-López, H.E.: 0000-0003-3133-0355

5 Author for correspondence. hebalagueral@unal.edu.co
\end{abstract}


associated with this hormone. In experiment 2 , the fruits refrigerated at $2{ }^{\circ} \mathrm{C}$, with or without the application of 1-MCP, had the longest postharvest duration, lasting 26 days, as compared to 12 days in the control fruits (without refrigeration and with $1-\mathrm{MCP}$ ). The fruits that lasted longer had a low respiratory rate during storage, as well as lower values for weight loss and, color index but, greater firmness and acidity. The 1-MCP was efficient when the fruits were at room temperature.

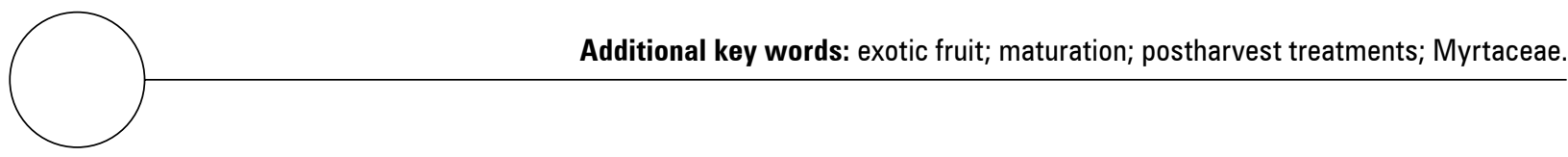

\section{RESUMEN}

La champa (Campomanesia lineatifolia) es una baya con sabor agradable y muy perecedera. El objetivo de este trabajo fue estudiar la regulación y prolongación de la vida poscosecha de los frutos de champa mediante el uso de 1-metilciclopropeno (1-MCP) y la refrigeración. Se realizaron dos experimentos, en el experimento 1 se evaluaron cuatro tratamientos para entender la regulación de la maduración, estos fueron: testigo, 1-MCP, etileno y 1-MCP+etileno, los frutos fueron almacenados a temperatura ambiente. En el experimento 2 se realizó la combinación de la aplicación o no de $1-\mathrm{MCP}$ y dos temperaturas de almacenamiento (ambiente $\left[16 \pm 2^{\circ} \mathrm{C}\right]$ y $2 \pm 0,4^{\circ} \mathrm{C}$ ). En los dos experimentos se utilizaron cuatro repeticiones, cada una con aproximadamente $500 \mathrm{~g}$ de frutos cosechados en estado 2 de madurez (25\% amarillos, 75\%verdes). Los resultados del experimento 1 indicaron que los frutos con 1-MCP presentaron la mayor duración poscosecha (17 días), firmeza, acidez titulable, también la menor tasa respiratoria y pérdida de peso durante los 10 días que estuvieron los frutos de todos los tratamientos, los frutos tratados con etileno tuvieron el comportamiento contrario, indicando que los cambios durante la maduración evaluados están asociados a esta hormona. En el experimento 2, los frutos refrigerados a $2{ }^{\circ} \mathrm{C}$ con o sin aplicación de 1-MCP tuvieron la mayor duración poscosecha con 26 días, en comparación con 12 días que duraron los frutos testigo (sin refrigeración y son 1-MCP), estos mismos frutos con mayor duración presentaron una muy baja tasa respiratoria durante el almacenamiento, menores valores de la pérdida de peso, menor índice de color, mayor firmeza y acidez. También se encontró que el 1-MCP es eficiente cuando los frutos están a temperatura ambiente.

Palabras clave: fruto exótico; maduración; tratamientos poscosecha; Myrtaceae.

Received: 18-02-2021 Accepted: 20-03-2021 Published: 30-03-2021

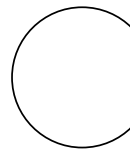

The champa (Campomanesia lineatifolia R. \& P., Mirtaceae) or "chamba" is a fruit tree whose fruits are edible berries. According to Silva and Fonseca (2016), this genus is characterized by its citrus-flavored fruits. It is an exotic fruit native to the Amazon rainforest that has considerable potential for commercialization and is currently being introduced in different markets in Colombia (Balaguera et al., 2009; Balaguera-López and Herrera, 2012a; Porras et al., 2020). This fruit has a high concentration of organic acids, sugars and volatile compounds (Balaguera and Herrera, 2012a), which makes it highly desirable for consumption, fresh or in processed products (Álvarez-Herrera et al., 2009a). In recent years, the champa has been reported as an important source of bioactive substances with great potential for use in the agricultural, pharmaceutical, cosmetic and food industries (Muños et al., 2015; Otálvaro-Álvarez et al., 2017).

However, the high perishability of champa fruit represents a major limitation of the product, which is responsible for considerable postharvest losses (Álvarez-Herrera et al., 2009a). In addition, its storage and marketing for fresh consumption have been limited by a lack of technological development (Muños et al., 2015). One way to reduce postharvest losses is to elucidate which processes are associated with ethylene during ripening for use as a basis for different 
technologies that reduce the biosynthesis and action of ethylene (Mariño-González et al., 2019) because ethylene is responsible for triggering processes at the physiological, biochemical and molecular levels (An et al., 2020), not only guaranteeing fruit ripening but also inducing senescence, an important cause of nutritional, physical and economic losses in agricultural products (Binder, 2008; Bapat et al., 2010). Therefore, several studies have looked at applications of ethylene and 1-methylcyclopropene (1-MCP) in fruits, which can done in a methodological way to determine the role of endogenous ethylene in ripening (Yang et al., 2013; Mariño-González et al., 2019).

1-MCP is a chemical compound that irreversibly occupies the membrane receptors of ethylene. At recommended doses, 1-MCP is not toxic to human beings and / or the environment; it is odorless and stable at room temperature. In addition, it is easy to apply and highly effective in protecting many agricultural species from the action of ethylene (Serek et al., 2006). It is not only considered as the main compound inhibiting ethylene action (In et al., 2013) but also as a commercial strategy commonly used for fruit and vegetable management (Lata et al., 2017). 1-MCP applications have generated delays in ripening processes in cape gooseberries (Physalis peruviana L.; Valdenegro et al., 2012), mangos (Razzaq et al., 2016), melons (Shi et al., 2014) and peaches (Mariño-González et al., 2019).

On the other hand, temperature is one of the most important factors that affect the quality of fresh produce. This is the reason why temperature management is a key tool for extending storage capacity and shelf-life in freshly harvested products, since it slows down both physiological and pathological deterioration with a decrease in metabolic processes, including respiration (Toivonen, 2016; Brasil and Siddiqui, 2018). Therefore, refrigeration is the most widely used and effective technology for reducing postharvest deterioration in fruit and vegetable products because it reduces commercial losses during storage (Lado et al., 2015). There is an optimal storage temperature for each product and the ideal temperature often depends on the geographical origin of the product (Brasil and Siddiqui, 2018). In champa fruits, there are no known studies involving the use of refrigeration. However, its use has been reported in different species: for instance, Obenland et al. (2013) found a better response in storage at $5^{\circ} \mathrm{C}$ with respect to $20^{\circ} \mathrm{C}$ in mandarins, cv. W. Murcott Afourer. In guava, an optimal storage temperature of $5-10^{\circ} \mathrm{C}$ has been reported (Parra-Coronado, 2014). Nonetheless, refrigeration and 1-MCP are the main techniques for increasing the postharvest shelf-life of tomato fruits (Zou et al., 2018). In pear fruits, refrigeration was also used effectively in combination with 1-MCP (Cheng et al., 2019).

The objectives of this study included: First, evaluate the application of 1-MCP and ethylene, individually and in combination, as well as compounds involved in the regulation of champa fruits to understand ethylene-dependent ripening processes found in the fruit. Second, determine the effect of 1-MCP and low temperatures as strategies to prolong the postharvest conservation and shelf life of these fruits.

\section{MATERIALS AND METHODS}

Champa fruits (Campomanesia lineatifolia R. \& P.), in stage 2 maturity (25\% yellow-75\% green; BalagueraLópez and Herrera, 2012b), were collected in the municipality of Miraflores, Boyaca (Colombia), from approximately 5-7-year-old trees, without agronomic management, but free of phytosanitary issues. This municipality is located at $1,432 \mathrm{~m}$ a.s.1., $5^{\circ} 11^{\prime} 49^{\prime \prime} \mathrm{N}$ and $73^{\circ} 08^{\prime} 47^{\prime \prime} \mathrm{W}$, with a mean temperature of $24^{\circ} \mathrm{C}$ and 2,500 $\mathrm{mm}$ of annual rainfall. The experiments were carried out in the Plant Physiology laboratory of the Universidad Pedagógica y Tecnológica de Colombia, which is part of the Faculty of Agricultural Sciences of this university.

Two experiments were carried out: The first one evaluated the effect of 1-MCP and ethylene, whereas the second one evaluated the effect of 1-Methylcyclopropene (1-MCP), as well as refrigeration.

Experiment 1. 1-MCP and ethylene: A completely randomized design was used with four treatments, repeated four times for a total of 16 experimental units, each consisting of $500 \mathrm{~g}$ of fruit. Such treatments were: ethylene $\left(1,000 \mu \mathrm{L} \mathrm{L}^{-1}\right), 1$-MCP $\left(0.35 \mathrm{mg} \mathrm{L}^{-1}\right)$, 1-MCP $\left(0.35 \mathrm{mg} \mathrm{L}^{-1}\right)+$ ethylene $\left(1,000 \mu \mathrm{L} \mathrm{L}^{-1}\right)$ and control without application.

$2 \mathrm{~L}$ containers were used for the application of ethylene in which a solution of $1,000 \mu \mathrm{L} \mathrm{L}^{-1}$ of ethephon (Ethrel ${ }^{\circledR} 48$ SL, Bayer CropScience) was prepared. The fruits were immersed in this solution for $10 \mathrm{~min}$ and then allowed to dry at room temperature. For the 1-MCP treatment, $2 \mathrm{~L}$ of a $0.35 \mathrm{mg} \mathrm{L}^{-1}$ solution of 1-MCP was made. The fruits were immersed for 10 
min and then left to dry at room temperature. For the 1-MCP + ethylene treatment, ethylene was applied 2 $\mathrm{d}$ after treatment. The fruits were then arranged in polystyrene trays and stored at room temperature $\left(16 \pm 2^{\circ} \mathrm{C}, 75 \pm 6 \% \mathrm{RH}\right)$. This methodology was slightly modified from Mariño-González et al. (2019).

Experiment 2. 1-MCP and refrigeration: In a second experiment, four treatments in a $2 \times 2$ factorial arrangement were evaluated with a completely randomized design. The first factor pertained to the application of 1-MCP, while the second factor corresponded to storage temperature $\left(2 \pm 0.4^{\circ} \mathrm{C}\right)$ and ambient $\left(16 \pm 2^{\circ} \mathrm{C}\right)$. Each of the experimental units involved a polystyrene tray with $500 \mathrm{~g}$ of fruit. The $1-\mathrm{MCP}$ was applied with the same procedure as in experiment 1.

In the two experiments, the following parameters were determined periodically during the storage process: until the fruits lost their organoleptic quality, which was visually estimated.

Determination of respiration rate: Approximately, $100 \mathrm{~g}$ of fruit were placed in a $2 \mathrm{~L}$ airtight chamber for $5 \mathrm{~min}$. In the chamber, an infrared $\mathrm{CO}_{2}$ sensor was placed (VER $\mathrm{CO}_{2}$-BTA), which was connected to a Labquest data collection device (Vernier Software and Technology, Beaverton, OR). The respiration rate was then calculated in mg CO $\mathrm{kg}^{-1} \mathrm{~h}^{-1}$ taking into account the weight of the fruits as well as the volume of the chamber (Mariño-Gonzalez et al., 2019). The epidermis color index (CI): was calculated with the following equation:

$\mathrm{IC}=\frac{1000 \times a^{*}}{\mathrm{~L}^{*} \times b^{*}}$

The CIEL*a* $b^{*}$ system parameters $L^{*}, a^{*}$ and $b^{*}$ were determined with a CR-410 colorimeter (Konica Minolta) with three inputs at the equatorial diameter. For weight loss (PP, \%), a sample of approximately $100 \mathrm{~g}$ of fruit was measured for fresh mass; and subsequently, the following equation was used:

$P P(\%)=\frac{(P 1-P 2)}{P 1} \times 100$

where, P1 is initial fruit weight, and P2 final fruit weight.

Fruit firmness $(\mathrm{N})$ was measured using a PCEPTR200 penetrometer. Soluble solids (SS; ${ }^{\circ}$ Brix) were defined using a digital refractometer (Hanna brand, Woonsocket, RI). The titratable acidity (TA; \% citric acid) was determined with acid-base titration with a $0.1 \mathrm{~N} \mathrm{NaOH}$ solution.

The data obtained statistically analyzed using Shapiro-Wilk and Levene's test, followed by analysis of variance and Tukey's test for comparison of means with $P \leq 0.05$ (Mariño-Gonzalez et al., 2019). Analyses were then carried out using SPSS v. 19.

\section{RESULTS AND DISCUSSION}

\section{Experiment 1. 1-MCP and ethylene}

The respiration rate of the champa fruits decreased in all treatments in the first $3 \mathrm{~d}$ of storage. However, it then had a continuous, significant increase in all treatments, which is typical of its climacteric character (Álvarez et al., 2009b). The rate was significantly higher $(P \leq 0.05)$ in the control fruits with the application of ethylene and, as a result, these fruits lost their organoleptic quality at $10 \mathrm{~d}$ after storage. The fruits with 1-MCP and 1-MCP +ethylene had a postharvest duration of $17 \mathrm{~d}$ and presented a maximum respiration rate of $60.1 \pm 4.2$ and $58.07 \pm 6.4 \mathrm{mg} \mathrm{CO}_{2}$ $\mathrm{kg}^{-1} \mathrm{~h}^{-1}$, respectively. During storage, these two treatments had a similar behavior (Fig. 1A).

The champa fruits with higher ethylene levels but without 1-MCP increased their respiration rate in a more characteristic way, because this hormone has the ability to stimulate respiration in fruits to induce the ripening process (Bapat et al., 2010; Kays, 2004), as found in peaches (Mariño-González et al., 2019). It has been found that ethephon can accelerate energy production, glycolytic metabolism and ethylene biosynthesis, processes that stimulate tissue respiration (Zhang et al., 2012). As a result of the inhibitory action on the receptors and the ethylene biosynthesis process (Balaguera-López et al., 2021), the application of 1-MCP was responsible for slowing down the respiratory rate in the champa fruits. This decrease in the respiratory rate with the ethylene inhibitor was responsible for a longer postharvest time of champa fruits, as reported by Daulagala and Daundasekera (2015) in avocado studies and by Cerqueira et al. (2009) in guava fruits. It is also important to note that the application of ethylene $2 \mathrm{~d}$ after 1-MCP did not reverse this effect. Respiration has a very important influence on fruit perishability, which indicates that 1-MCP may become a practical alternative for 


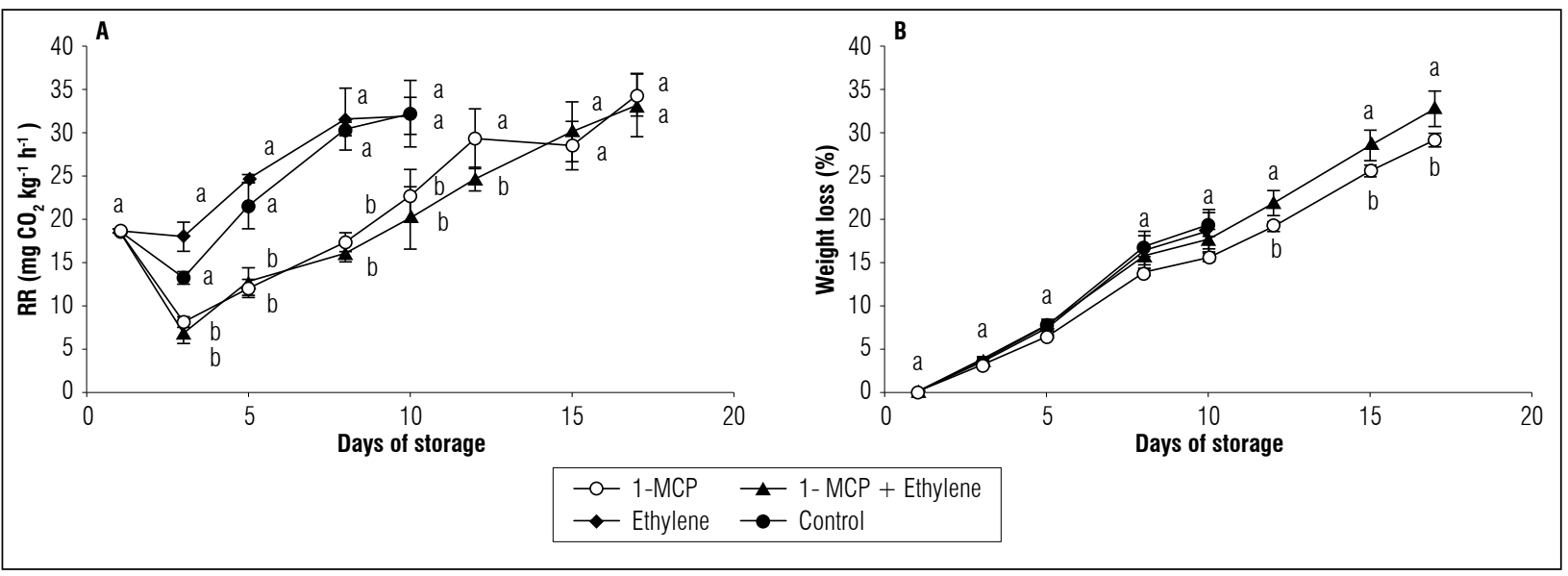

Figure 1. A) Respiration rate (RR) and B) weight loss of champa fruits under postharvest applications of 1-MCP and ethylene. The vertical bars in each mean value indicate the standard error $(n=4)$. Means followed by different letters in each measurement indicate significant differences according to the Tukey's test $(P<0.05)$.

improving the postharvest life and quality of champa fruits.

Weight loss in all fruits increased progressively. While the fruits in all treatments were in commercial quality $(10 \mathrm{~d})$, there were no statistical differences. However, after this point, the fruits with 1-MCP+ethylene significantly lost weight. Eventually, losses for these two treatments were $32.7 \pm 0.8$ and $29.1 \pm 2 \%$, respectively (Fig. 1B). Since this fruit is characterized by considerable weight loss (Balaguera-López and Herrera, 2012b), this may explain why there were no differences between treatments until day 10. The fact that the fruits with 1-MCP, with and without ethylene, presented the greatest weight loss was due to the fact that they remained at room temperature for longer because they had a longer postharvest duration, as was reported by Balaguera-López and Herrera (2012b).

The color index of the epidermis had a continuous for the storage. This increase represented a change in color from green to yellow. The CI was statistically higher in the fruits with ethylene and in control fruits with values higher than 4 . The fruits with 1-MCP presented a longer postharvest duration and,

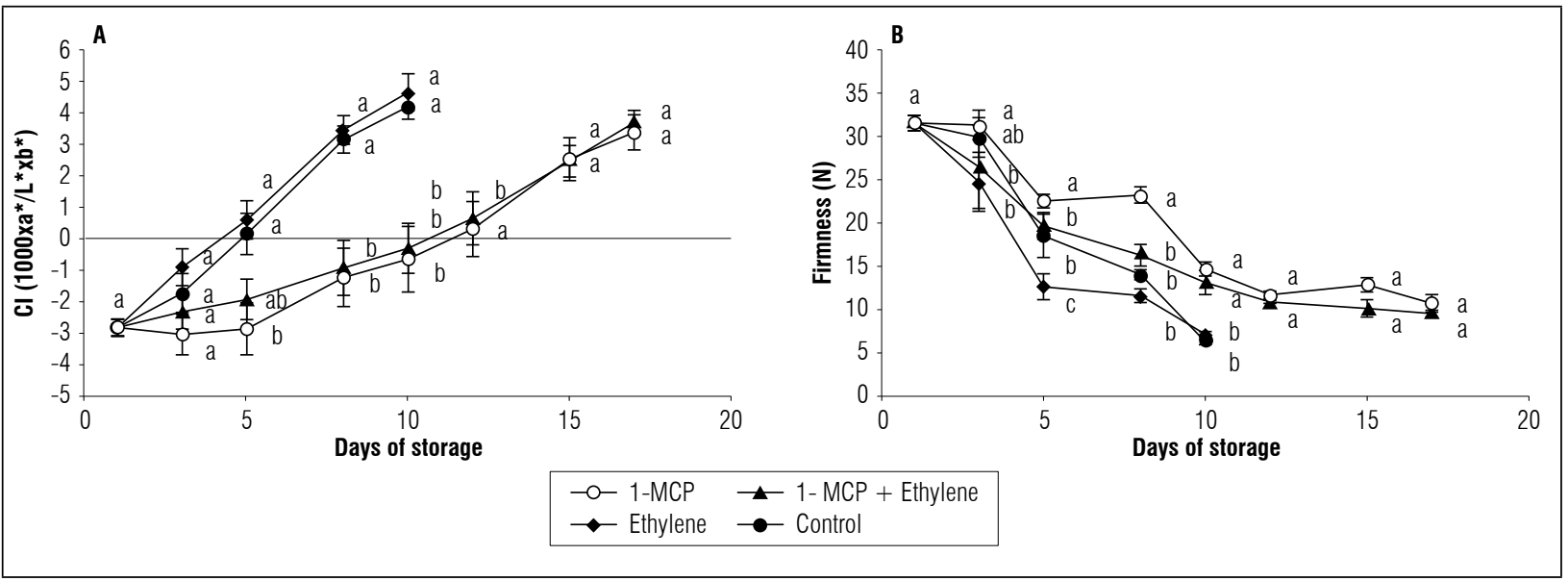

Figure 2. A) Epidermis color index and B) firmness of champa fruits under postharvest applications of 1-MCP and ethylene. The vertical bars in each mean value indicate the standard error $(n=4)$. Means followed by different letters in each measurement indicate significant differences according to the Tukey's test $(P<0.05)$. 
a slower color change but had similar values from 12 $\mathrm{d}$ to the end of storage $(17 \mathrm{~d})$. At this point, the $\mathrm{CI}$ was close to 3.7 (Fig. 2A).

The untreated champa fruits, as well as the fruits with ethylene presented a greater and rapid change in the epidermis color. This change can be explained not only by the high level that these fruits were assumed to have -which stimulates the degradation of chlorophylls through chlorophyllase enzymes- but also by to the increase in the synthesis of carotenoids, which favors the characteristic yellow color of this species (Álvarez-Herrera et al., 2009b), highlighting the importance of this hormone in the regulation of fruit color. For the application of 1-MCP, the significant delay in CI indicates the effectiveness of this compound at avoiding the action of ethylene, thus delaying the activation of processes related to color change in the champa fruits. This result has also been evidenced in feijoa fruits (Rupavatharam et al., 2015).

Changes in color can be ethylene-dependent or ethylene-independent (Lelievre et al., 1997). Therefore, the results presented here indicate that, in the champa fruits, color was ethylene-dependent, as found in peaches and cape gooseberries (Mariño-González et al., 2019).

A loss of firmness was observed during storage in all fruits. Significant differences $(P \leq 0.05)$ were observed from day 3 to $10 \mathrm{~d}$ of storage. It was evident that the fruits with 1-MCP, alone or with ethylene, delayed softening, and eventually, the fruits presented more than $15 \mathrm{~N}$ (Fig. 2B). 1-MCP affects biosynthesis, signaling, and, as a result, processes that depend on ethylene during ripening, in this specific case, firmness. This is done by decreasing the activity of hydrolase enzymes that mainly affect the cell wall, including polygalacturonase, whose activity is reported for this species (Balaguera-López and Herrera, 2012a). Consistently, several studies have indicated that 1-MCP decreases softening in other Myrtaceae fruits, such as guava and feijoa (Cerqueira et al., 2009; Rupavatharam et al., 2015). Enzymes that are involved in the loss firmness such as polygalacturonase, pectin methylesterase, endo- $\beta-1,4$-glucanase, $\alpha$-arabinosidase and $\beta$-galactosidase, have higher activity with ethylene applications because the expression of related genes increases (Nishiyama et al., 2007; Pech et al., 2008). This may explain the greater softening in the control and ethylene-added champa fruits at the beginning of storage, was an indication that firmness in this species is apparently regulated by ethylene.

An increase in fruit TA was observed up to $5 \mathrm{~d}$. of storage and then decreased until loss of commercial quality. There were statistical differences only at $10 \mathrm{~d}$ since the control fruits and fruits with ethylene had the lowest TA. The fruits with 1-MCP -alone or in combination-continued to lose TA. However, at $17 \mathrm{~d}$ of storage, they presented the lowest values throughout all storage process, with a TA of approximately $2 \%$ (Fig. 3A).

This fruit is characterized by high acidity values (about 3\%), which can increase during ripening (Balaguera-López and Herrera, 2012a, b). The decrease

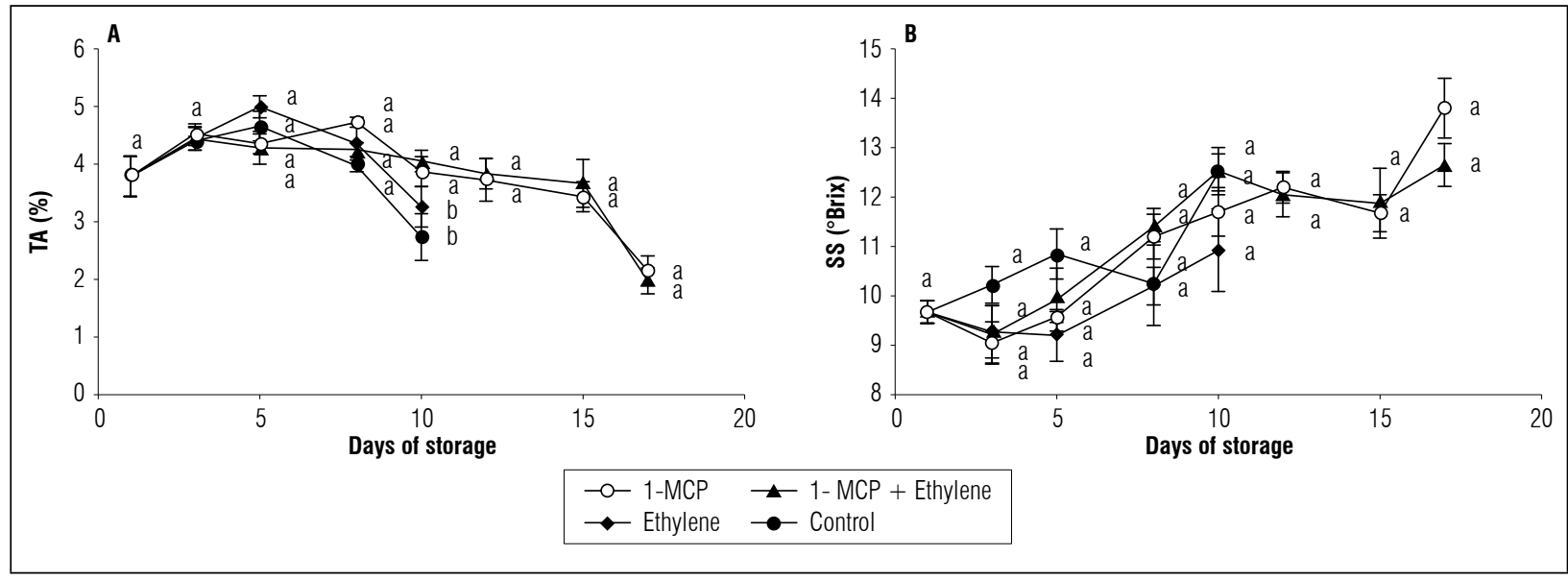

Figure 3. A) Titratable acidity and B) Soluble solids of champa fruits under postharvest applications of 1-MCP and ethylene. Vertical bars in each mean value indicate the standard error $(n=4)$. Means followed by different letters in each measurement indicate significant differences according to the Tukey's test $(P<0.05)$. 
observed after $5 \mathrm{~d}$ in all treatments may have been the result of increased metabolic expenditure, which includes respiration and gluconeogenesis (Kays, 2004; Toivonen, 2016). However, it is important to indicate that at $10 \mathrm{~d}$, ethylene stimulates the expenditure of organic acids, whereas the use of 1-MCP delays it. This result was closely related to the one obtained in respiration (Fig. 1A), which also showed that TA metabolism may be regulated by ethylene. Barreto et al. (2017) showed similar results in peaches, finding higher acidity in fruits treated with 1-MCP than in fruits treated with ethylene, the latter accelerating the loss of acidity in these fruits. It was found that 1-MCP decreased the degradation of organic acids in guava fruits (Singh and Pal, 2008).

There were no significant differences in any of the samplings and the tendency was to increase the SS. At the beginning of the experiment, the fruits presented less than $10^{\circ}$ Brix, whereas the fruits with $1-\mathrm{MCP}$ accumulated approximately $14{ }^{\circ}$ Brix (Fig. 3B). This increase in SS may have been due to the hydrolysis of starch and reserve polysaccharides (Kays, 2004). This metabolism is expected to be regulated by ethylene. However, since acids are constituents of SS and, in this study, accounted for between 28 and $54 \%$ of the $\mathrm{SS}$ value, they can easily affect them. Therefore, there was not enough evidence to affirm or rule out that SS were regulated by ethylene in the present study.

\section{Effect of 1-MCP and refrigeration}

Significant differences $(P \leq 0.05)$ were observed from day 3 to $19 \mathrm{~d}$ in the respiration rate. Thus, there was a decrease between day 1 and $3 \mathrm{~d}$. The refrigerated fruits (with and without 1-MCP) maintained a constant respiration rate throughout storage, whereas the fruits at room temperature showed a continuous increase that was related to the postharvest duration. The control fruits lost their organoleptic quality at 12 $\mathrm{d}$ of storage, and their respiration rate was $59.1 \pm 4.2$ $\mathrm{mg} \mathrm{CO} \mathrm{kg}^{-1} \mathrm{~h}^{-1}$. In contrast, the fruits at room temperature with 1-MCP lasted until $19 \mathrm{~d}$, while the refrigerated fruits remained for $26 \mathrm{~d}$, and their respiration rate did not exceed $13 \mathrm{mg} \mathrm{CO}_{2} \mathrm{~kg}^{-1} \mathrm{~h}^{-1}$ (Fig. 4A).

The champa fruits with 1-MCP at room temperature decreased their respiration rate, as compared to the control fruits, through inhibition of the ethylene receptors (Lata et al., 2017), as previously mentioned. However, there was no effect when $2^{\circ} \mathrm{C}$ refrigeration was used, which was possibly due to the fact that refrigeration may decrease the affinity or interaction of 1-MCP with ethylene receptors, or perhaps the decrease in the solubility of 1-MCP in the cell, as mentioned by Mir et al. (2001) and Villalobos et al. (2011). It has been mentioned that refrigeration is used in order to decrease the respiration rate, thus preserving the quality of the fruit and delaying senescence. With this decrease in respiration, both the metabolic and enzymatic activities of fruits are reduced (Pereira et al., 2013). Wu et al. (2015) reported that at postharvest, the activities of antioxidant enzymes (CAT, SOD and POD) are very important for scavenging ROS to protect cell membranes and delay senescence. This explains the duration of $26 \mathrm{~d}$ in the use of refrigeration, as compared to the $12 \mathrm{~d}$ in the fruits without treatments. Concordant results were

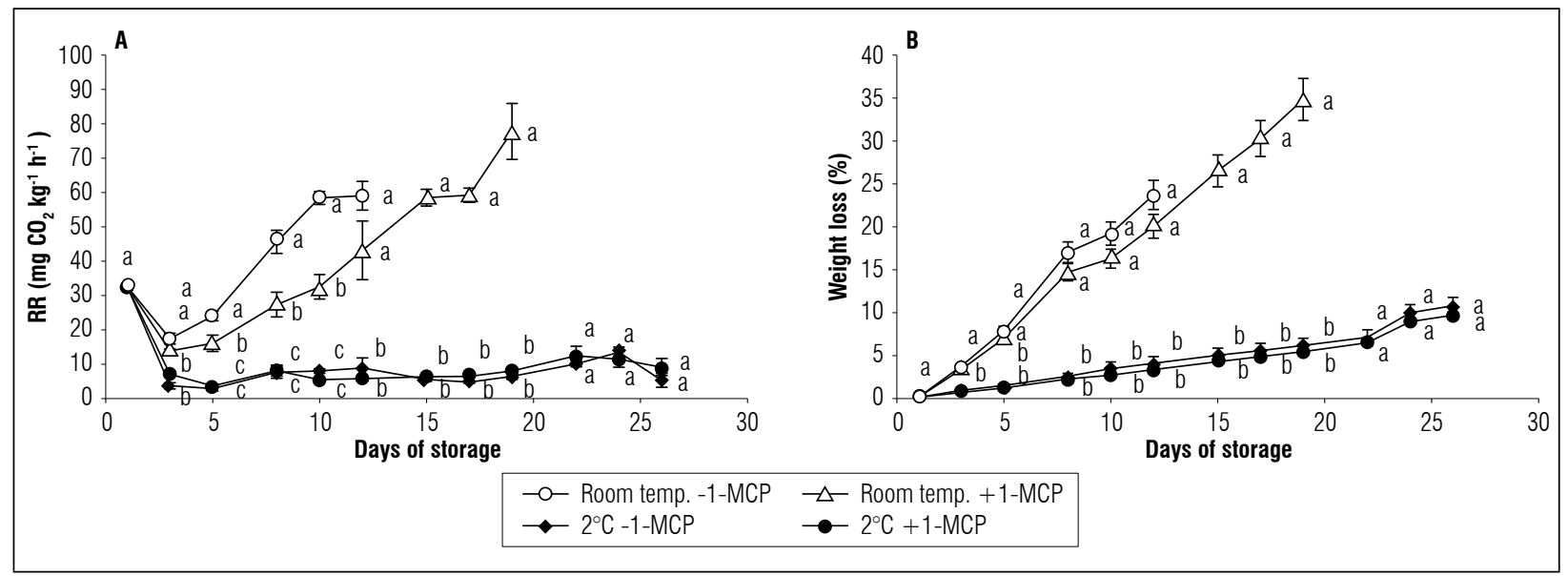

Figure 4. Effect of postharvest application of 1-MCP and refrigeration on: A) respiration rate and B) weight loss of champa fruits. Vertical bars in each mean indicate the standard error $(n=4)$. Means followed by different letters in each measurement indicate significant differences according to the Tukey's test $(P<0.05)$. 
found by Balaguera-López et al. (2015) in cape gooseberry fruits, and by Carrillo et al. (2011) in Eugenia stipitate (araza) fruits, where refrigeration reduced the respiration rate and extended the postharvest conservation.

Continued weight loss was evident during storage. The fruits under refrigeration -regardless of the addition of 1-MCP- had statistically the lowest weight loss, resulting in a $11 \%$ loss of their weight after 26 d. The control fruits lost $23.7 \pm 1.7 \%$ of their weight, whereas the fruits at room temperature with 1-MCP lost $34.8 \pm 2.5 \%$ (Fig. $4 \mathrm{~B}$ ). Refrigeration, in addition to decreasing respiration in the champa fruits, may have delayed deterioration and thus water loss by transpiration, as previously mentioned in other studies (Toivonen, 2016; Brasil and Siddiqui, 2018). Likewise, Carrillo et al. (2011) found that 1-MCP, together with storage at $7^{\circ} \mathrm{C}$, reduced weight loss in araza fruits.

The color index of the control fruits changed rapidly, and a value of $4.1 \pm 0.7$ was obtained at $12 \mathrm{~d}$. The fruits at room temperature with the addition of 1-MCP had statistically similar values to the fruits under refrigeration until $12 \mathrm{~d}$. However, they had a marked increase in their CI until $19 \mathrm{~d}$. The fruits under refrigerated storage, with and without 1-MCP, slowly changed the epidermis color with a CI greater than zero toward the end of the storage period (Fig. $5 \mathrm{~A})$.

The 1-MCP was efficient when was compared with the control. This result may have been due to the fact that this compound decreases the activity of the enzyme chlorophyllase and therefore the loss of chlorophyll (Lata et al., 2017), delaying color change. However, when 1-MCP was used at $2^{\circ} \mathrm{C}$, there was no significant effect in relation to refrigeration alone, perhaps because of the significant decrease in metabolism at this temperature.

It is possible that the lower $\mathrm{CI}$ in the refrigerated fruits was due to a lower loss of chlorophylls and less accumulation of carotenoids, as a result of a slower ripening process. In addition, it is well known that low storage temperatures reduce metabolic activity (Toivonen, 2016). In tomato fruits, it was found that refrigerated storage delayed color change because of a lower accumulation of carotenoids (Rugkong et al., 2011). It is important to clarify that there were no visible symptoms of cold damage during storage such as peel pitting or external browning. However, evaluations with shelf-life periods are suggested to be completely sure that $2^{\circ} \mathrm{C}$ does not cause physiopathologies in champa fruits.

The treatments at room temperature showed a more accelerated loss of firmness than the treatments under refrigeration. The treatment with 1-MCP together with refrigeration maintained greater firmness of the fruits during the storage period and presented a final firmness of $19.9 \pm 1.5 \mathrm{~N}$ (Fig. 5B).

It is known that one of the main causes of softening in fruits is the activity of enzymes that hydrolyze polysaccharides (Kays, 2004). It has been found that

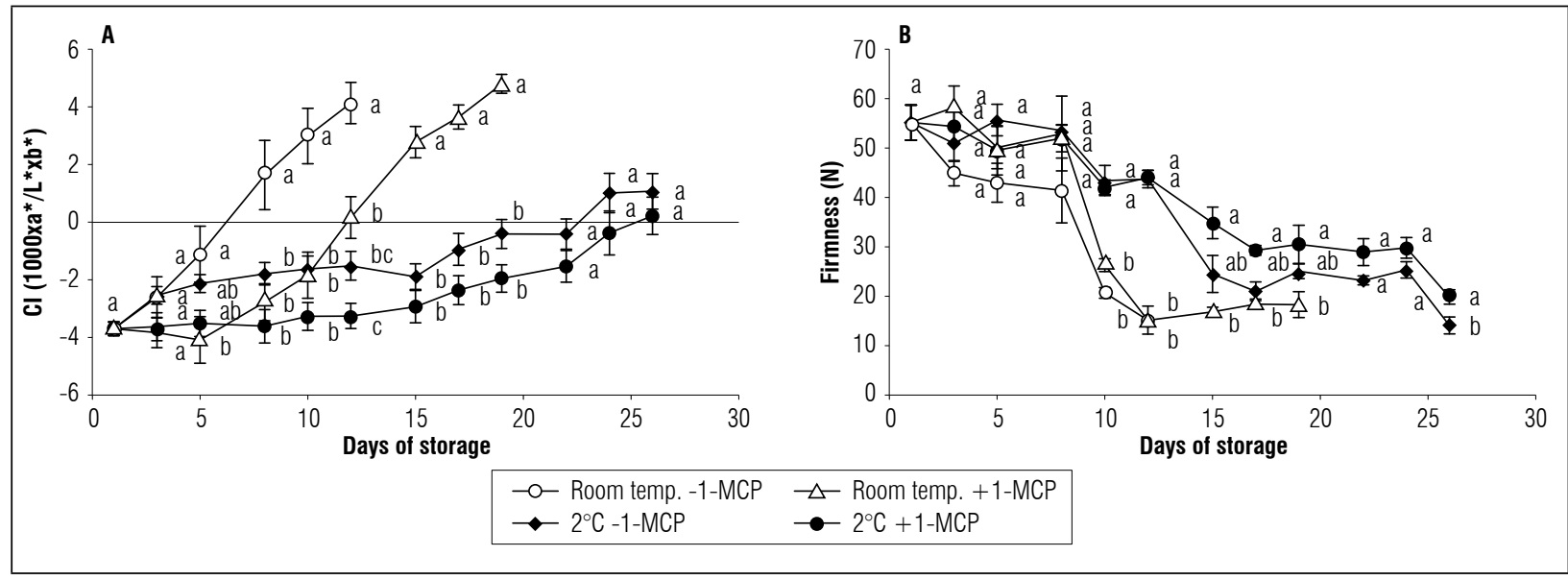

Figure 5. Effect of postharvest application of 1-MCP and refrigeration on: A) the color index of the epidermis and B) the firmness of champa fruits. The vertical bars in each mean indicate the standard error $(n=4)$. Means followed by different letters in each measurement indicate significant differences according to the Tukey's test $(P<0.05)$. 
the depolymerization of pectins and xyloglucan are regulated positively by ethylene (Nishiyama et al., 2007; Pech et al., 2008). For this reason, the champa fruits with 1-MCP had slightly higher firmness and a longer postharvest duration than the control fruits. However, the greatest favorable effect on firmness was generated by a low temperature, possibly because of the fact that low temperatures have the capacity to decrease the genes expression involved in process of ethylene biosynthesis, which leads to decreased ethylene biosynthesis and reduced cell wall degradation, as has been reported in tomato fruits (Rugkong et al., 2011). In the same species, refrigeration decreased the activity of polygalacturonase and pectin methyl esterase 1 enzymes (Rugkong et al., 2010). This shows the importance of refrigeration in maintaining champa fruit firmness.

For titratable acidity, there were significant statistical differences from 8 to $19 \mathrm{~d}$ of storage. Although there was an increase in acidity in the first days of storage, a decrease was later evident; however, it was more marked in the fruits at room temperature. At the end of the storage period, the refrigerated fruit had higher TA values, around $3.5 \%$ (Fig. 6A). These results indicate the favorable effect of low temperatures in the decrease of metabolism -mainly respiration- as observed in figure $4 \mathrm{~A}$, which in turn decreases the consumption of organic acids and maintains a higher level of TA. As observed in the previous parameters, 1-MCP had no effect when the champa fruits were stored at $2{ }^{\circ} \mathrm{C}$. On the other hand, refrigeration at $2{ }^{\circ} \mathrm{C}$ and the use of 1-MCP maintained the highest TA values during the storage period in cape gooseberry fruits (Balaguera-López et al., 2015).

In general, there were no significant changes in SS during storage, but there was a slight increase in all treatments between the beginning and the end of this period. There were statistical differences $(P \leq 0.05)$ only at $15 \mathrm{~d}$, at which point the fruit with 1-MCP at room temperature had the highest SS values $\left(9.4 \pm 0.5^{\circ} \mathrm{Brix}\right)$, as compared to the refrigerated fruits, with or without 1-MCP applications (Fig. 6B). This result could have been due to the fact that the champa fruits at room temperature presented higher enzymatic activity related to carbohydrate metabolism, which increased soluble sugars. With refrigeration, the increase in SS was lower because the ripening process was delayed. The favorable effect of low temperatures on SS has also been found in tomato fruits (Getinet et al., 2008).

\section{CONCLUSIONS}

Ripening processes such as respiration, epidermis color and firmness of champa fruits were stimulated with the application of ethylene and delayed with the application of 1-MCP. Therefore, they are ethylene-dependent processes. Refrigeration at $2^{\circ} \mathrm{C}$, with or without the addition of 1-MCP, maintained the fruits for 25 days because of a decrease in the respiration rate, weight loss, color index and loss of firmness. 1-MCP was effective only at room temperature,

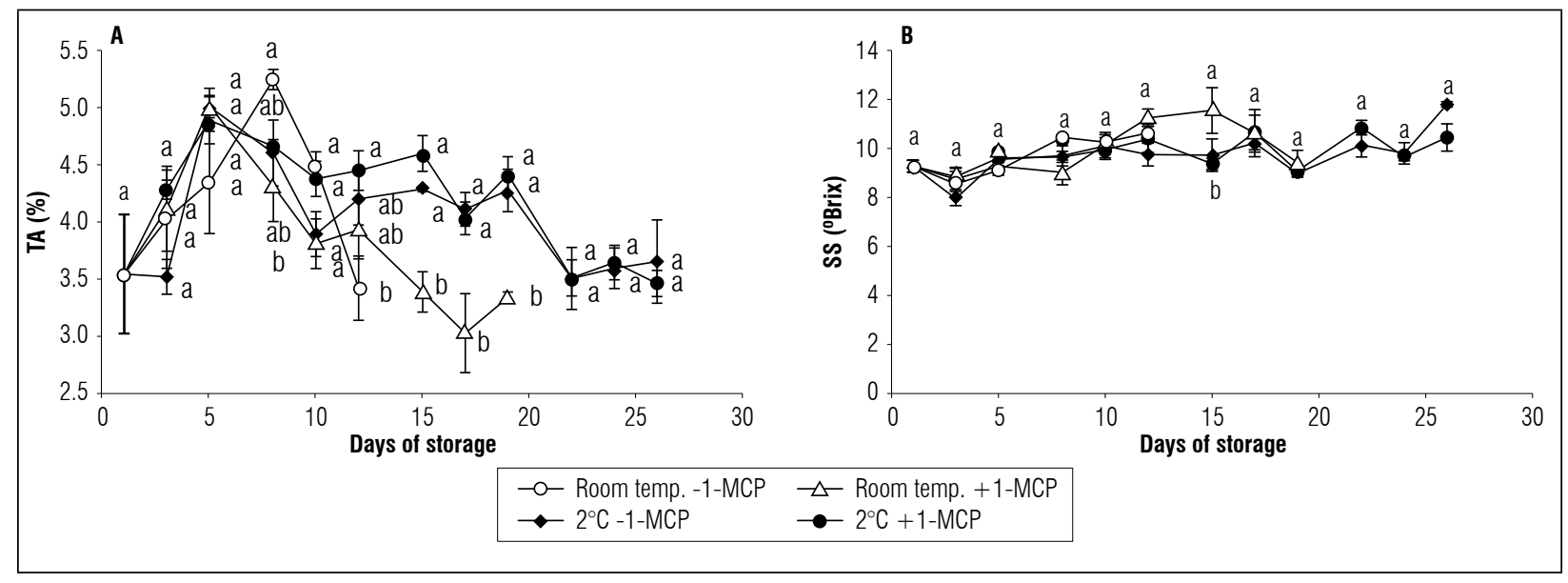

Figure 6. Effect of the postharvest application of 1-MCP and refrigeration on: A) Titratable acidity and B) Soluble solids of Champa fruits. The vertical bars in each mean indicate the standard error $(n=4)$. Means followed by different letters in each measurement indicate significant differences according to the Tukey's test $(P<0.05)$. 
which is recommended for improving the postharvest conservation of champa fruits.

Conflict of interests: The manuscript was prepared and reviewed with the participation of the authors, who declare that there exists no conflict of interest that puts at risk the validity of the presented results.

\section{BIBLIOGRAPHIC REFERENCES}

Álvarez, J.G., H.E. Balaguera-López, and J.F. Cárdenas. 2009b. Caracterización fisiológica del fruto de champa (Campomanesia lineatifolia Ruiz. \& Pavón), durante la poscosecha. Rev. U.D.C.A. Actual. Divulg. Cient. 12(2), 125-134. Doi: 10.31910/rudca.v12.n2.2009.698

Álvarez-Herrera, J.G., J.A. Galvis, and H.E. Balaguera. 2009a. Determinación de cambios físicos y químicos durante la maduración de frutos de champa (Campomanesia lineatifolia R. \& P.). Agron. Colomb. 27, 253-259.

An, J., R.A. Almasaud, M. Bouzayen, M. Zouine, and C. Chervin. 2020. Auxin and ethylene regulation of fruit set. Plant Sci. 292, 110381. Doi: 10.1016/j. plantsci.2019.110381

Balaguera, HE., J.G. Álvarez, and D.C. Bonilla. 2009. Crecimiento y desarrollo del fruto de champa (Campomanesia lineatifolia Ruiz \& Pavón). Rev. U.D.C.A. Actual. Divulg. Cient. 12(2), 113-123. Doi: 10.31910/rudca. v12.n2.2009.697

Balaguera-López, H.E., M. Espinal-Ruiz, J.M. Rodríguez-Nieto, A. Herrera-Arévalo, and L. Zacarías. 2021. 1-Methylcyclopropene inhibits ethylene perception and biosynthesis: a theoretical and experimental study on cape gooseberry (Physalis peruviana L.) fruits. Postharvest Biol. Technol. 174, 111467. Doi: 10.1016/j. postharvbio.2021.111467

Balaguera-López, H.E. and A. Herrera. 2012a. Estudio de algunos cambios bioquímicos durante el crecimiento y hasta la cosecha del fruto de champa (Campomanesia lineatifolia R. \& P. Familia Myrtaceae). Rev. Bras. Frutic. 34(2), 460-468. Doi: 10.1590/ S0100-29452012000200019

Balaguera-López, H.E. and A. Herrera. 2012b. Determining optimal harvest point for champa (Campomanesia $i$ neatifolia R. \& P.) fruit based on skin color. Ing. Investig. 32(1), 88-93.

Balaguera-López, H.E., C.A. Martínez, and A. Herrera. 2015. Refrigeration affects the postharvest behavior of 1-methylcyclopropenetreated cape gooseberry (Physalis peruviana L.) fruits with the calyx. Agron. Colomb. 33(3), 356-364. Doi: 10.15446/agron.colomb. v33n3.51896

Bapat, V.A., P.K. Trivedi, A. Ghosh, V.A. Sane, T.R. Ganapathi, and P. Nath. 2010. Ripening of fleshy fruit:
Molecular insight and the role of ethylene. Biotechnol. Adv. 28,94-107. Doi: 10.1016/j.biotechadv.2009.10.002

Barreto, C.F., R.R. Zandoná, G. Acorsi, A. Copatti, and J. Saavedra. 2017. Efeito do 1-Metilciclopropeno na qualidade pós-colheita de pessegos 'Chiripá'. Rev. Iberoam. Tecnol. Postcos. 18(1), 33-38.

Binder, B. 2008. The ethylene receptors: complex perception for a simple gas. Plant Sci. 175, 8-17. Doi: 10.1016/j. plantsci.2007.12.001

Brasil, I. and M.W. Siddiqui. 2018. Postharvest quality of fruits and vegetables: An Overview. pp. 1-40. In: Siddiqui, M.W. (ed). Preharvest modulation of postharvest fruit and vegetable quality. Academic Press, London.

Carrillo, M.P., M.S. Hernández, J. Barrera, O. Martínez, and J.P. Fernández-Trujillo. 2011. 1-Methylcyclopropene delays arazá ripening and improves postharvest fruit quality. LWT - Food Sci. Technol. 44, 250-255. Doi: 10.1016/j.lwt.2010.05.029

Cerqueira, T., A. Jacomino, F. Sasaki, and L. Amorim. 2009. Controle do amadurecimento de goiabas 'Kumagai' tratadas com 1-metilciclopropeno. Rev. Bras. Frutic. 31(3), 687-692. Doi: 10.1590/S0100-29452009000300010

Cheng, Y., L. Liu, Y. Feng, Y. Dong, and J. Guan. 2019. Effects of 1-MCP on fruit quality and core browning in 'Yali' pear during cold storage. Sci. Hortic. 243, 350356. Doi: 10.1016/j.scienta.2018.08.041

Daulagala, C.H. and W.A.M. Daundasekera. 2015. Effect of 1-methylcyclopropene (1-MCP) treatment on postharvest quality and antifungal activity of avocado cv. 'pollock' under tropical storage conditions. Ceylon J. Sci. (Bio. Sci.) 44(2), 75-83. Doi: 10.4038/cjsbs. v44i2.7352

Getinet, H., T. Seyoum, and K. Woldetsadik. 2008. Effect of cultivar, maturity stage and storage environment on quality of tomatoes. J. Food Eng. 87, 467-478. Doi: 10.1016/j.jfoodeng.2007.12.031

In, B.C., J. Strablea, B.M. Binder, T.G. Falbel, and S.E. Patterson. 2013. Morphological and molecular characterization of ethylene binding inhibition in carnations. Postharvest Biol. Technol. 86, 272-279. Doi: 10.1016/j. postharvbio.2013.07.007

Kays, S. (ed.). 2004. Postharvest biology. Exon Press, Athens, GA.

Lado, J., O. Cronje, M.J. Rodrigo, and L. Zacarías. 2015. Resistance to chilling injury in red, lycopene-accumulating tissue of cold-stored grapefruits. Acta Hortic. 1079, 249-256. Doi: 10.17660/ActaHortic.2015.1079.29

Lata, D., V.S. Kuchi, and G.A. Nayik. 2017. 1-methylcyclopropene (1-MCP) for quality preservation of fresh fruits and vegetables. J. Postharvest Technol. 5(3), 9-15.

Lelievre, J.M., L. Tichit, P. Dao, L. Fillion, Y.W. Nam, J.C. Pech, and A. Latche. 1997. Effects of chilling on the expression of ethylene biosynthetic genes in 
Passe-Crassane pear (Pyrus communis L.) fruits. Plant Mol. Biol. 33, 847-855. Doi: 10.1111/j.1399-3054.1997. tb01057.x

Mariño-González, L., C. Buitrago, H. Balaguera-López, and E. Martínez-Quintero. 2019. Effect of 1-methylcyclopropene and ethylene on the physiology of peach fruits (Prunus persica L.) cv. Dorado during storage. Rev. Colomb. Cienc. Hortic. 13(1), 46-54. Doi: 10.17584/rcch.2019v13i1.8543

Mir, N.A., E. Curell, N. Khan, M. Whitaker, and R.M. Beaudry. 2001. Harvest maturity, storage temperature, and 1-MCP application frequency alter firmness retention and chlorophyll fluorescence of 'Redchief Delicious' apples. J. Am. Soc. Hortic. Sci. 126, 618-624. Doi: 10.21273/JASHS.126.5.618

Muños, C.W., R.W. Chávez, L.C. Pabón, F.M.R. Rendón, M.P. Chaparro, and A.M. Otálvaro-Álvarez. 2015. Extracción de compuestos fenólicos con actividad antioxidante a partir de champa (Campomanesia lineatifolia). Rev. CENIC Cienc. Quim. 46, 38-46.

Nishiyama, K., M. Guis, J.K.C. Rose, Y. Kubo, K.A. Bennett, and L. Wangjin. 2007. Ethylene regulation of fruit softening and cell wall disassembly in Charentais melon. J. Exp. Bot. 58, 1281-1290. Doi: 10.1093/jxb/erl283

Obenland, D., S. Collin, J. Sievert, and M.L. Arpaia. 2013. Mandarin flavor and aroma volatile composition are strongly influenced by holding temperature. Postharvest Biol. Technol. 82, 6-14. Doi: 10.1016/j. postharvbio.2013.02.013

Otálvaro-Álvarez, A.M., L.C. Pabón-Baquero, M.R. Rendón-Fernández, and M.P. Chaparro-González. 2017. Extractos de Campomanesia lineatifolia para el control del pardeamiento enzimático en papa mínimamente procesada. Cienc. Agric. 14(2), 39-48. Doi: 10.19053/01228420.v14.n2.2017.7147

Parra-Coronado, A. 2014. Maduración y comportamiento poscosecha de la guayaba (Psidium guajava L.). Una revisión. Rev. Colomb. Cienc. Hortic. 8(2), 314-327. Doi: 10.17584/rcch.2014v8i2.3223

Pech, J.C., M. Bouzayen, and A. Latche. 2008. Climacteric fruit ripening: ethylene-dependent and independent regulation of ripening pathways in melon fruit. Plant Sci. 175, 114-120. Doi: 10.1016/j.plantsci.2008.01.003

Pereira, D., M. Rodrigues, J. Da Costa, R. Pires, and C. Horst. 2013. Cold storage of peaches cv. Aurora grown in the zona da Mata Mineira, Minas Gerais State, Brazil. Rev. Ceres 60(6), 833-841. Doi: 10.1590/ S0034-737X2013000600012

Porras, Y., M. Pedreros, W. Reyes, and H. Balaguera-López. 2020. Efecto de la luz sobre la germinación de semillas de champa (Campomanesia lineatifolia $\mathrm{R}$. \& P.). Cienc. Agric. 17(2), 23-31. Doi: 10.19053/01228420.v17. n2.2020.10979
Razzaq, K., Z. Singh, A.S. Khan, S.A.K.U. Khan, and S. Ullah. 2016. Role of 1-MCP in regulating 'Kensington Pride' mango fruit softening and ripening. Plant Growth Regul. 78(3), 401-411. Doi: 10.1007/ s10725-015-0101-7

Rugkong, R., R. McQuinn, J.J. Giovannoni, J.K.C. Rose, and C.B. Watkins. 2011. Expression of ripening-related genes in cold-stored tomato fruit. Postharvest Biol. Technol. 61, 1-14. Doi: 10.1016/j.postharvbio.2011.02.009

Rugkong, R., J.K.C. Rose, S.J. Lee, J.J. Giovannoni, M.A. O'Neill, and C.B. Watkins. 2010. Cell wall metabolism in cold-stored tomato fruit. Postharvest Biol. Technol. 57, 106-113. Doi: 10.1016/j.postharvbio.2010.03.004

Rupavatharam, S., A.R. East, and J.A. Heyes. 2015. Re-evaluation of harvest timing in 'Unique' feijoa using 1-MCP and exogenous ethylene treatments. Postharvest Biol. Technol. 99, 152-159. Doi: 10.1016/j. postharvbio.2014.08.011

Serek, M., E.J. Woltering, E.C. Sisler, S. Frello, and S. Sriskandarajah. 2006. Controlling ethylene responses in flowers at the receptor level. Biotechnol. Adv. 24, 368381. Doi: 10.1016/j.biotechadv.2006.01.007

Silva, C.A. and G.G. Fonseca. 2016. Brazilian savanna fruits: characteristics, properties and potential applications. Food Sci. Biotech. 25(5), 1225-1232. Doi: 10.1007/ s10068-016-0195-3

Shi, Y., B. Wang, D. Shui, L. Cao, C. Wang, T. Yang, and H. Ye. 2014. Effect of 1-methylcyclopropene on shelf life, visual quality and nutritional quality of netted melon. Food Sci. Technol. Int. 21(3), 175-187. doi: 10.1177/1082013214520786

Singh, S. and R. Pal. 2008. Response of climacteric-type guava (Psidium guajava L.) to postharvest treatment with 1-MCP. Postharvest Biol. Technol. 47(3), 307314. Doi: 10.1016/j.postharvbio.2007.08.010

Toivonen, P.M.A. 2016. Postharvest physiology of fruits and vegetables. pp. 49-79. In: Pareek, S. (ed.). Postharvest ripening physiology of crops. Taylor and Francis, London. Doi: 10.1201/b19043

Valdenegro, M., L. Fuentes, R. Herrera, and M.A. Moya-León. 2012. Changes in antioxidant capacity during development and ripening of goldenberry (Physalis peruviana L.) fruit and in response to 1-methylcyclopropene treatment. Postharvest Biol. Technol. 67, 110-117. Doi: 10.1016/j.postharvbio.2011.12.021

Villalobos, M., W. Biasi, E. Mitcham, and D. Holcroft. 2011. Fruit temperature and ethylene modulate 1-MCP response in Bartlett pears. Postharvest Biol. Technol. 60, 17-23. Doi: 10.1016/j.postharvbio.2010.11.005

Wu, B., Q. Guo, G. Wang, X. Peng, J. Wang, and F. Che. 2015. Effects of different postharvest treatments on the physiology and quality of 'Xiaobai' apricots at 
room temperature. J. Food Sci. Technol. 52(4), 22472255. Doi: 10.1007/s13197-014-1288-8

Yang, X., J. Song, L. Campbell-Palmer, S. Fillmore, and Z. Zhang. 2013. Effect of ethylene and 1-MCP on expression of genes involved in ethylene biosynthesis and perception during ripening of apple fruit. Postharvest Biol. Technol. 78, 55-66. Doi: 10.1016/j. postharvbio.2012.11.012

Zhang, L., L. Jiang, Y. Shi, H. Luo, R. Kang, and Z. Yu. 2012. Post-harvest 1-methylcyclopropene and ethephon treatments differently modify protein profiles of peach fruit during ripening. Food Res. Int. 48, 609619. Doi: $10.1016 /$ j.foodres.2012.05.022

Zou, J., J. Chen, N. Tang, Y.Q. Gao, M.S. Hong, W. Wei, H.H. Cao, W. Jian, N. Li, W. Deng, and Z.G. Li. 2018. Transcriptome analysis of aroma volatile metabolism change in tomato (Solanum lycopersicum) fruit under different storage temperatures and 1-MCP treatment. Postharvest Biol. Technol. 135, 57-67. Doi: 10.1016/j. postharvbio.2017.08.017 